Произведены чстире операции кеслрева сечения по акушерским поқазаниям (клини чески узкий таз, тазовое предлежание в сочетания с ранним отхождением околоплодных воА и возрастом женцины, тазовое прел межание в сочетанин с тенденцией $\mathrm{k}$ крушно пиони и обвитиж путовины вокруг шеи) Послеродовый период у нсех женщин про ходик без особенностей.

Проведеншые нсслсдования Позволиют предположить, что зйтония и умереніная сим патикотония в покое в сочетании с симпа тикотоническим и асимйтккотоническим ти пами ВР в третьем гриместре беремености, вегетативиое пбеслечение физической дея тельности с усилением тонуса симпатического отдела́ ВНС ПереА родами "влнжтся, тоо видимому, оптимальными Аля реализации адатационых реакций организма при бере меншости, обеспечивают еє физиологическое течение и благоноучный исход родог. Раз лнчие же двух грути, вероятіо, ввАяется отражением различных вариалтов нормаль. ных уровней фуюкционировання систем на фоне которых протекает гестация

Таким образом, ири физиолотическом те чении беременности адаптационғне процес сы по обеспечению вегетативного гомеостаза осуществляются За счет усиления тонуса сим патоаденалового звена, степени активации киторого зависит от исхолного функциональ ного состояния регулирукоцих систем. ГТлу чснные Нами Аанные ПоАТВерЖааюТся зако пом гомеостаза об исходном уровне (закон "началықого значения "У Уйласра): чем вылте. уровен: исходной актињшости физиологичес кого состояния, тем меньше онносительнуе изменение этого уровня при воздейстиия импульсь одной и тий же интенсивности.

\section{AKTEPATYPA}

1. Алчерева В.Ф. Ненрологические осложнешия при поздних токсикозах беремешных.-Киев, 1982.

2. Боевскиё Р.М. //Математические методы ананиза серденико ритма-М., 1968.

3. Баенекий Р.М., Киримов О.И., Клечкин С.З. Матема тический анализ изменений сердечного рима при стрегсе-М., 1984

4. Белоконь Н.А., Кубертер М.Б. Болезни сералыа и согу АОв у Аетей.-M., 1987

5. Вациико С.А. Поздний токсихоз беуеменньх, нару

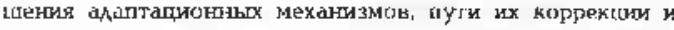
профилактики: Аитореф. Анс. ... канд. мел. наук.-Кнев, 1981.

6. Газазян М.Г. //Ақушерство и гинехологин - 1989. No. 5. - C. $59-60$.

7. Ayga ИВ. //Акушерство и гинекология,-1984.-№ $7-\mathrm{C} .6-9$.

8. Жарнин А. D., Ањ Асаф Юсеф, Фофанов С.И. //Аку шерство и гицекология.-1985.-№ 8.-С.5-9

9. Заболевания вететативной нервной системы: Рук водство дяя врачей /Под ред. А.М.Кейна.-М., 1991.

10. Кулпков В.И., Проихина И.В. Экстрезияе родоразре шение.--M., 1994.

11. Сандаконл E.A. Церебральные вєетатигные нару шения при раннем гестозе: Антореф. дик. ... камд мед наук.-Пермн. 1903

12. Серан B.Н月, Слинжаков А.Н, Маркан С.А. Гіракти ческое акунеретво.-М., 1989.

13. Скрябина В.н. Состояние вегетативной нервной

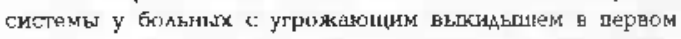
триместре беремепюист: Азтореф. Аис. ... кать. меА. наук.-Перми, 1994.

14. Шехтман M.M. ААаптация организма к овремен ности: Актоная речь. М.. 1991

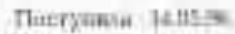

YAK $616.125-007-07$

\author{
M.Salaschek, R.Winkel
}

\title{
DETECTING A PATENT FORAMEN OVALE BY TRANSCRANIAL DOPPLER SONOGRAPHY (TCD)
}

(5 years of clinical experience with a new method)

Dept. of Neurology, von-Bodelschwingh Krankenhaus, Schutstr. Ibbenbüren, FRG

A b s t r a c t. In patients with cerebral ischemid of unknown origin, paradoxical embolism must be considered as one of the possible causes, if there is an abnomal right-to. left shunt. The most likely site of tranmission is a perststing patent foramen ovale (PFO), which is found in approximately $30 \%$ of adult persons in autopsy studies, [Jsing transcranial Doppler sonography (TCD) and an agitated saline solution as an inexpensive and readily available contrast medium, probably all clinically important right to-left shunts can be defected. in our department we examined 215 patjents within the last 5 years. $30 \%$ of which bad an abnormal right-to-left shunt with insignificant divference between 10 and 69 years of age.
M. Casaneк, P.Buнkerb

НЫЯВАЕНИЕ АЕФЕКТА ОВААВНОГО ОТВЕРСТИЯ

С ПОМОЩЦК ТРАНСКРАНИАМНОЙ АОППМЕРСОНОГРАФИИ

(5-летний кинцуескнй опыт примсшсния noвoru метоAа)

В числе вероятных шричин ицемического инсуягта может бить парадоксалыная эмболия в условия аномального право- и левосторонцего межпредсердното игута. Основнам нутем заброса змбола является функпионируко. 


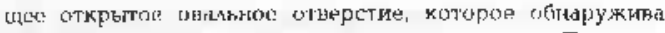

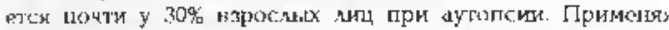

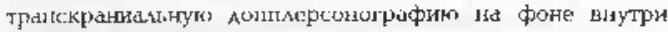

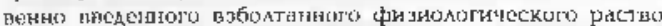

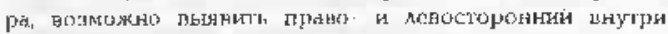

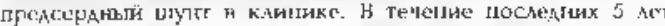

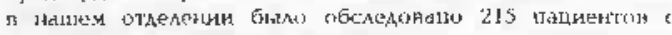

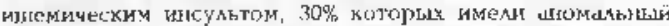

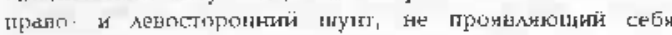

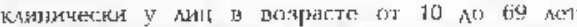

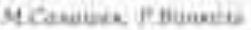

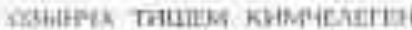

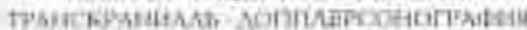

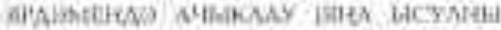

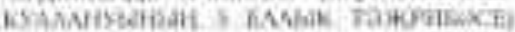

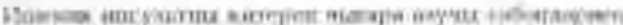

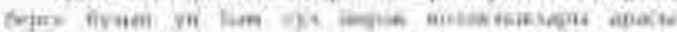

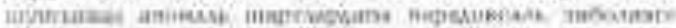

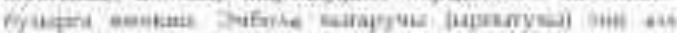

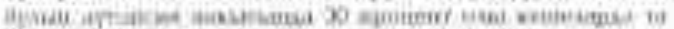

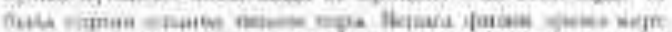

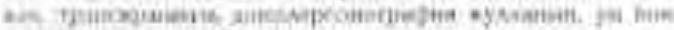

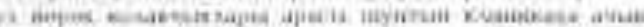

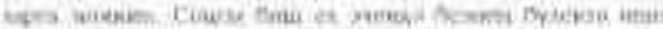

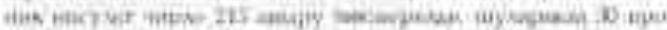

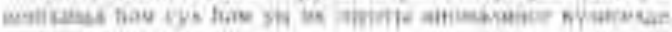

P aradoxical emboli as a causs of cerebral ischerias have drawn increasing atterntion of vascular neurologisls, as in a considerable num ber of piztients mo other viscular, cardiac or thrombogenic cause of stroke can be lound. it is estinated, that about $15 \%$ of all ischemic. sirokes are coused by a paradoxical cmabolizalion via a pofentially open foramen ovale |1|. Smiall thrombi may spontaneously form in one of the derp veins of the legs or the pelvis, especially when a person sits or lies without moving for several homrs. When such a thrombus becomes an cmbolus, it must redch a cortain size, to affecl the funclion of the lung, usually about. $8-10 \mathrm{ml}$. However, a blood clol Inuch sindler thar Ihis may already occlude a cerebral artery long enougti to prouluce a transient or perma nent. ischesmic deficit. All it needs is an abnormai right-to left shunt. 'Jhe most likely location of this shunt is a palenl foramen ovale (PFO). In rare cases, shunts on the pulmonary level are ilso possible.

The prevalence of a right to left shunt can be assessed by intravenous application of an ultrasound contrast-medium, which is unable to pass the lung and by detecting traces of this medium in the arterial system, either in the left half of the heart by transesophageal echocar diography (contrast-TEE) or by transcranial Doppler sonography (contrast-TCD). Using contrast TEE as a standard, the sensitivity of contrast-TCD was reported to be about $90 \%$ $\{5,6]$, the sperificity about $93 \% \quad[6,7\}$. Both methods proved to be similarly efficient to de tect small amounts of echo-contrast bubbles [8|. especially during the Valsalva maneuver However, the i.v.-contrast-TCD me1hod is more convenient for examiners and patients; it is available in more neurological oflices or de parlments, and it can detecl. not only a $\mathrm{PFO}$ but also abnormal shunts on the pulmonary level.

The autopsy incidence of $\mathrm{P \Gamma O}$ kas been reported to be approximately $30 \%$ [3], whereas ultrasonod contrasi TEE reveals only aboul $10 \%$ of PFO in normal patients |?. In younger persons wilh cerebrovascular events of unknown source, however, the incidence of $\mathrm{PFO}$, as detec ted by contrast. TEE or contrast TCD, is reported to to approximalely $50 \% \quad|1,6|$.

\section{METIIOD}

As an ultrasound contrasl medium we use agitafed saline solutions according to 'Touge and Sharma 7 l: 7--9 $\mathrm{ml}$ of salire solutuon are mixed with 2 inl of fresh venous blood and about $0.1 \mathrm{ml}$ of air belween two hypodermic syrusess altached to a 3-way adapler. Some? of bur castes were also examined with $10 \mathrm{ml}$ of Echoviste (micro air bubbles surrourded by it thin layer (1) galactose), showing identical resulls. in 1991-1994 unilateral examinations of the middle? cerebral artery with a hand hrid probs on the alfecled side of the brain were performed during and after repeated i.v injuctions of ultrasound contrasl solutions into a cubulal vein without and with a Valsdlva maneuve?. [n case of a recyative result this procedure was repeated on the corlralnteral middle cerebral artery, in some casses also after changing the side of jujeclion. Since 1995 bildterd examinations of both middle ceretmal arleries were perfumed using two probes fixed with a special hed gear simultaneously. Appearance of contrastenhanced signals within 8--10 hearl cycles were considered to prove a PFO. repreated delay of microembolic signals until the $11^{\text {th }}$ cardiac cycle or lister werc suspicious of a pulmoridry shumt.

\section{KESULIS}

Up to now, we examirned 215 patients (108 male, 107 female) with sudden cerebral events suspicious of ischemias. Most of these? cases were thought to be thrombo embolic, but some may have had vasculitis (clevaled ANA titer). complicated migraine (migraine accompagnee), or disturbed coagulation (e.g. elevated anti cardiolipine Jevels). Two cases with multiple sclerosis also had a PFO, and neither case history nor clinical examination or MRI could distinguish between individual lesions caused by demyelinization or by ischemias. None of the palients had stcnoses of the extra or intra cranial arteries (al) were examined by Doppler and duplex sonography) or possible cardial sources of emboli (normal ECG and echocar diography). Of these 215 patients 65 (33 mate- 
32 female, averaging $30 \%$ ) with a persisting right to left shunt were detected, only two of them with a pulmonary location lone with severe chronic obslructive lung uisease, the other one wilh Osler's teleangiectasis). The examinalion methot had no side ceffects.

Bilateral lesting was nol significantly superior to unilaterki testing; most cases had positive echo conlmast signals in both middle cerebral artaries, so that unilateral examinations were sufficient, even when using a hand hejd probe. Fixiry the probes with a special head gear, however, had the advantage of fewer artifacis and of fewer injections of contrast mediun needed. The incidence of an abnomal shunt was not significantly influenced by age; in every subgroup between 10 and 79 yexis of age about $30 \%$ of the rises had a right to heff shunt with the highest incidence between 60 and 69 years $(36 \%)$ (see ligure?)

\section{DISC USSION}

Paradoxical embolism may be ai colusc of stroke at any age, and contrast TCl) is a rela. tively reliable and easy to use method of detec: ling a possible site of transtrission. Yet our results of aboul $30 \%$ of abnormal Iefl.to right shunts in patients suspicious of cerebral ischemias withoul any other cardiac or vascular cause seem to be somewhat less effertive lhan those reported elsewhere in recent literature. We consider several explanations

a) our pulients include some with possilyle other reasons for cerebral ischemia, some with complicated nigrairse (early eommunisations suggested, that a PFO may be the true source of the vascular complications), some? with multiple sclerosis, and some with a disorder of their coagutation; we could not possibly exclude the lalter group, as a disorder in coagulation may be one of the reasons, why a blood clot will form in the deep veins before it becomes $a$ paradoxical embolus;

b) instead of an expensive pharmareutical preparalion like Echovist ${ }^{(1)}$ wo used aģilated saline solutions will blood and minule amounts of air. The costs of this preparation are near to nothing. However. Echovist ${ }^{\circledR}$ may be somewhat more slable:

c) the cubital vein may not be the optimal site for injecting a contrast medium, which stro uld pass through an aperture of the atrial septum. Recent unpublished communications suggest, that the femoral vein may yield better results. If a cubital vein is used, it may help to elevale the arm and teli the pulienl to use his muscie pump during injection of the contrast medium ank the Valsalva maneuver [1]

By injecting an ayitated saline solution into a cubitil vein insteid of Echovist into the femoral vein, we may have missed a PFO in d few percent of our patients. We assume, however, that if a PFO is missed, it must be very smail and unlikely lo form a possible sites of transmission for a paratoxical emboius. We therefore recommend agitated sabine solutions as relatively reliable and inexpensive contrast media when used with transcranial Doppler (TCD) in the search for an abrurmal left to. right shunling

A palent foramen ovale, however, dues not. recessirily induce a cerebro-vascular event, just as it carotid stenosis is nol always the suurce of a cerebral ischemia. Careful exploration of the case history in respect for situations, in which deep venous clot formation could have occurred, and careful physical examinutions are always necessary [4]. Sudics of the crogulatory status may be useful. I'reventive treatuneril rrus? be adjusted to each individual case. In a lew pationis 10 contimuous Ireatment may be necessary, with the exception of injecting heparin, whenever a Ionger rest is unavoidable. Cigarette smoking ought to be discontinued in cvery case. In our female patients the intake of estrngens was discouraged. A few patients received conlinuous anticodyulant therapy. 'l'ht? patient with Osler's teleangieclasis in his lumy was successfully treated by interventional angiography (particle-ocriusion) of the malforincilions.

\section{I.TERATURE:}

1. Dieht, Bertil (1996ị: Funktione]lu Dopplersonongaphie in der Neurologie. Berlin, Heidelberg etc

2. Fisher et al. (1995). Cinest 107: 1504-1509.

3. Hagen el al. (1944) Mayo Chin I'T⿰亻: 59: 17-20

4. Hartsurma, Salaschek (1992) Nervenat; 63: 761-762

5. Job el al. (1994) Arn J Cardiol. 4. 381-384.

G. Ktolssch et al. (1994) Neurology 9: 1603-1606.

7 Lectrat et of. (1581) N Engl J Med 3id 1148--1152

8. Teage, Sharma (1991) Stroke 22: 740-- 745 .

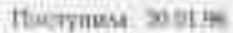

